\title{
FORMALISASI SYARI'AT ISLAM DAN DOMINASI NEGARA TERHADAP ELITE AGAMA ISLAM TRADISIONAL DI ACEH
}

\author{
Nirzalin $^{1 \bowtie}$, Fakhrurrazi $^{2}$ \\ ${ }^{1}$ Staf Pengajar Sosiologi Politik Universitas Malikussaleh Lhokseumawe, Aceh, Indonesia \\ ${ }^{2}$ Staf Pengajar Ilmu Sosial Budaya Dasar Universitas Malikussaleh Lhokseumawe, Aceh, Indonesia
}

Permalink/DOI: http://dx.doi.org/10.15294/komunitas.v6i1.2948

\section{Article History \\ Received : Desember 2013 \\ Accepted : Januari 2014 \\ Published : Maret 2014}

\section{Keywords}

Formalization of Islamic Syari'ah; Political Role of Teungku Dayah; Aceh

\begin{abstract}
Berdasarkan studi kasus di Aceh Utara, tulisan ini hendak menunjukkan realitas kompleks tentang komodifikasi Syari'at Islam oleh elite yang sedang memerintah di Aceh. Realitasnya, birokratisasi Syariat Islam telah menutup ruang bagi lahirnya wacana tandingan (counter discourse) dari masyarakat terhadap wacana yang dikembangkan oleh negara. Hal itu termanifestasi pada pelbagai Qanun yang telah disahkan. Qanun-qanun tersebut justeru memperlihatkan dominasi kepentingan elite yang sedang memerintah daripada aspirasi yang disuarakan oleh masyarakat. Sementara itu, birokratisasi dayah (pondok pesantren salafi/tradisional) dan penciptaan ketergantungan ekonomi dayah pada negara melalui kegiatan yang mengatasnamakan "pembinaan" dayah ternyata merupakan kedok bagi dominasi negara terhadap teungku dayah (elite agama Islam tradisional). Dominasi ini berhasil memposisikan teungku dayah sebagai jastifikator pelbagai kebijakan pemerintah. Akibatnya, peran teungku dayah di Aceh yang pada awalnya adalah aktor sosial yang secara vis $a$ vis sanggup berhadapan dengan pemerintah dalam mengkritisi pelbagai kebijakan berdasarkan aspirasi yang berkembang di masyarakat menjadi pudar.
\end{abstract}

\section{FORMALIZATION OF ISLAMIC LAW \& THE STATE'S DOMINANCE OVER TRADITIONAL MUSLIM ELITES IN ACEH}

\begin{abstract}
Abstrak
Based on a case study in North Aceh district, this paper wants to demonstrate the complex reality of current commoditization of Syari'ah committed by political elites in Aceh. In fact, the bureaucratization of Syari'ah has closed democratic spaces which enable civil society including local religious elite to counter state's discourses and policies. Such bureaucratization was manifested in the enactment of several Qanuns which unveil the domination of ruling elites' interests over society's interests and aspiration. On the other hand, the bureaucratization of dayah (traditional or salafi pesantren) and the formation of its economic dependence on state's budgets through what called as "dayah guidance/direction programs" became a powerful means for the state apparatus to co-opt teungku dayah as Islamic local religious elites. Such cooptation has successfully positioned teungku dayah to act as justificatory actor toward various government policies. As the result, the historical role of teungku dayah in Aceh as the main political actor, which able to criticize government policies based on people aspiration, is fading away in the aftermath of conflict in Aceh.
\end{abstract}

(C) 2014 Universitas Negeri Semarang

${ }^{\otimes}$ Corresponding author:

ISSN 2086-5465

Address: Kampus Utama Cot Tengku Nie Reuleut, Muara Batu, Aceh Utara,

Provinsi Aceh, Indonesia

E-mail: nirzalinarmia@yahoo.co.id 


\section{PENDAHULUAN}

Islam dan orang Aceh tidak dapat dipisahkan. Sebab, Islam tidak hanya memberi basis nilai terhadap rujukan tindakan, namun lebih dari itu Islam merupakan sistem pandangan dunia (worldview) yang menuntun orang Aceh menilai baik-buruk dan benar salahnya sesuatu. Kenyataan ini meletakkan landasan tingginya pengaruh elite agama Islam terhadap masyarakatnya di wilayah ini. Di Aceh elite agama Islam lokal ini dipanggil dengan sebutan teungku dayah $^{1}$. Mereka merupakan pemberi tafsir terhadap ajaran-ajaran Islam yang bersifat normatif sehingga dapat dipahami oleh masyarakat sebagai umat. Pengetahuan Islam yang luas dan mendalam yang bersumber dari kitab-kitab kuning yang dipandang sebagai sumber utama ajaran Islam oleh masyarakat Aceh menempatkan masyarakat amat tergantung pada teungku dayah. Sebab tanpa teungku dayah tidak mungkin masyarakat dapat memahami ajaran Islam itu karena kitab-kitab kuning tersebut tertulis dalam bahasa Arab gundul (tanpa harakat). Maka pemahaman terhadap kitab kuning hanya mungkin dikuasai oleh mere-ka yang mengerti bahasa Arab.

Di Aceh, kelompok sosial yang mempelajari bahasa Arab dan kitab kuning ini adalah teungku dayah. Cakupan ajaran Islam yang tidak hanya menyangkut persoalan-persoalan hubungan antara umat dan Tuhan tetapi juga wilayah-wilayah sosial dan politik memberi landas tumpu bagi luasnya pengaruh teungku dayah di Aceh. Kenyataannya, penempatan referensi tinda-

1 Teungku Dayah adalah sebutan masyarakat Aceh terhadap ulama. Teungku dayah ini sepadan artinya dengan sebutan Buya dalam masyarakat Minang, Ajengan dalam masyarakat Sunda dan Kyai dalam masyarakat Jawa. Mereka dipercaya berpengetahuan (agama Islam) luas, memimpin dan lulusan dari dayah tradisional (pesantren salafi) yaitu dayah yang hanya mempelajari ilmu-ilmu agama Islam, berdomisili di gampoeng (daerah pedesaan) dan kharismatik. Lihat, Nirzalin, Relasi Kekuasaan Teungku-Murid, Studi di Dayah Tanoh Abeu Kabupaten Aceh Besar, (Lhokseumawe: LPPM Universitas Malikussaleh, Penelitian Hibah Propinsi Nanggroe Aceh Darussalam, 2004), hlm. 15 dan Zamakhsyari Dhofier, Tradisi Pesantren, Studi Tentang Pandangan Hidup Kyai, (Jakarta: $\mathrm{LP}_{3} \mathrm{ES}$, 1982), hlm. 55 kan masyarakat pada apa "kata"nya teungku dayah menyebabkan mereka tampil sebagai aktor yang menentukan di Aceh baik dalam ranah agama, sosial maupun politik disepanjang penggalan sejarahnya (Nirzalin, 2012: 165-241).

Namun tatkala syariat Islam pada era pascaOrde Baru dan konflik dilegalisasikan penerapannya peran dominan dan menentukan itu berangsur-angsur memudar. Realitasnya, teungku dayah tidak mampu lagi mengintervensi kebijakan pemerintahan sekalipun itu berkaitan dengan permasalahan sensitif yang mengancam integrasi nasionalisme etnik Aceh seperti isu tentang wali nanggroe dan bendera dan lambang Aceh. Qanun No. 7 Tahun 2012 Tentang Wali Nanggroe dan Qanun No. 3 Tahun 2013 Tentang Lambang dan Bendera Aceh melahirkan kontroversi dan bahkan menjurus huru hara di beberapa wilayah Aceh terutama pantai Barat, Selatan dan Tengah.

Qanun yang pertama dicurigai oleh kelompok minoritas suku di Aceh (Gayo, Alas dsb) sebagai qanun yang menafikan eksistensi mereka sebagai suku asli Aceh yang juga memiliki hak sama dengan suku Aceh mayoritas. Masalahnya qanun tersebut secara eksplisit menyebut bahwa yang berhak menjadi wali nanggroe adalah orang Aceh asli dan fasih berbicara dalam bahasa Aceh. meskipun dalam qanun tersebut juga dikatakan bahwa yang dimaksud dengan bahasa Aceh adalah bahasa-bahasa yang hidup dan berkembang dalam masyarakat Aceh (Qanun No. 7 Tahun 2012 Tentang Wali Nanggroe Pasal 1).

Sementara qanun lambang dan bendera Aceh ditentang oleh sebagian masyarakat Aceh terutama yang berdomisili di pantai barat, selatan dan tengah karena jelas-jelas menetapkan bendera bulan bintang sebagai bendera Aceh. Bendera ini dilihat dari segi bentuk dan warnanya adalah bendera GAM (Gerakan Aceh Merdeka) di masa konflik. Sebagian masyarakat Aceh yang berdomisili di luar pantai timur itu menentang bendera ini karena mereka mengangap elite pemerintahan Aceh pascakonflik yang didominasi oleh mantan kombatan GAM berusaha menjustifikasi isu 
ditingkat nasional dan internasional bahwa orang Aceh adalah GAM. Padahal tidak semua orang Aceh GAM. Kuatnya penolakan terhadap dua isu tersebut bahkan menguatkan kembali tuntutan pemekaran provinsi Aceh Leuser Antara (ALA) dan Aceh Barat Selatan (ABAS). Tuntutan yang dinilai oleh mayoritas masyarakat Aceh sebagai ancaman terhadap integrasi Aceh secara teritorial maupun etno-nasionalisme.

Hiruk-pikuk pertentangan wacana antara masyarakat dan pemerintah Aceh itu tidak mendapat respon berarti dari teungku dayah. Padahal sebagai panutan umat, dalam panggung sejarah politik Aceh mereka selalu berada digarda terdepan baik memediasi maupun bahkan mengintervensi kebijakan pemerintah agar bersesuaian dengan kepentingan dan aspirasi masyarakat. Dalam konteks itu tulisan ini mengeskplorasi bagaimana formalisasi syari'at Islam di Aceh? Bagaimana pula dominasi negara terhadap elite agama Islam lokal (teungku dayah) melalui formalisasi syari'at Islam itu? Terakhir bagaimana dampak dominasi negara itu terhadap kewibawaan politik teungku dayah di Aceh?

\section{PERSPEKTIF TEORITIK DAN METODE PENELITIAN}

Menurut Pareto (2006), dalam masyarakat selalu terdapat dua lapisan sosial. Pertama, lapisan yang rendah (non elite), dan kedua, lapisan yang tinggi atau elite yang terbagi ke dalam dua kelompok pula yaitu kelompok elite yang memerintah dan kelompok elite yang tidak memerintah. Kelompok elite yang memerintah adalah kelompok minoritas yang mengendalikan pemerintahan, sementara kelompok elite yang tidak memerintah terdiri dari kelompok elite ekonomi lokal (hartawan) yang berpengaruh dan kelompok relijius (agamawan).

Dalam masyarakat Aceh elite agama ini disebut dengan teungku dayah. Meskipun hanya sebagai pemimpin informal namun mereka merupakan panutan dan penentu sikap serta tindakan-tindakan masyarakat dalam pelbagai persoalan seperti menyikapi perbedaan-perbedaan, konflik, sikap politik dan pelbagai aktivitas pem- bangunan (Alfian, 1975: 18). Karena itu, di Aceh teungku dayah sebagai elite agama merupakan agen sosial yang selalu diharapkan mampu menjalankan tanggung jawab moralnya yaitu menjaga kepentingan masyarakat dan menawarkan perubahan-perubahan yang dinilai baik menurut nilai-nilai Islam yang diyakininya. Dalam konteks itu, maka tindakan-tindakan agensi teungku dayah dalam mempengaruhi struktur (negara) agar melalui pelbagai kebijakannya senantiasa berpihak pada kepentingan masyarakat menjadi suatu keniscayaan. Realitas tersebut bersesuaian dengan pandangan Giddens, bahwa menjadi agen berati menjadi aktor sosial di mana dia selalu dituntut terlibat dalam mengintervensi rangkaian peristiwa-peristiwa (Antony Giddens, 1984: 5-30).

Agen sebagai pelaku dituntut selalu mampu mempengaruhi peristiwa dalam lintas ruang dan waktu. Karena itu perubahan-perubahan ruang dan waktu menuntut agen mampu mengadaptasikannya sehingga agen harus selalu mampu merefleksikan dan memonitoring tindakan-tindakannya. Karena itu dalam konsep strukturasi Giddens persoalan waktu dan ruang memiliki arti yang sangat sentral. Berbeda dengan Goffman yang memahami waktu dan ruang sebagai arena atau panggung tindakan (stage), kemana kita masuk dan darimana kita keluar. Giddens dengan diilhami oleh filsafat waktu Heidegger, menyatakan bahwa waktu dan ruang bukanlah arena atau panggung tindakan, melainkan unsur konstitutif dan pengorganisasian masyarakat. Artinya, tanpa waktu dan ruang tidak ada tindakan (B.Herry-Priyono, 2002: 20). Konsep praksis Giddens ini sejalan dengan perspektif Bourdieu. Menurut Boudieu (2004), praksis berada dalam ruang dan waktu. Ruang dan waktu dapat dimodelkan dengan pelbagai cara, sehingga dapat dikonstruksi secara sosial dengan egaliter. Namun, gerakan dalam ruang selalu melibatkan gerakan dalam waktu. Praksis, sebagai satu fenomena sosial yang tampak dan objektif tidak dapat dipahami di luar konteks ruang/waktu. Segala analisis praksis yang memadai harus memperlakukan temporalitas sebagai karakteris- 
tik sentral di dalam inti analisisnya.

Situasi ini menuntut agen selalu memiliki kapasitas pengetahuan yang mumpuni sehingga ia mampu terus-menerus mengintervensi setiap peristiwa yang selalu berubah dalam lintas ruang dan waktu. Karena itu, teungku dayah sebagai agen selalu dituntut menjadi figur yang berpengetahuan tinggi di masyarakatnya sehingga ia mampu mengendalikan kewacanaan masyarakat dalam relasi sosial yang terbangun. Wacana yang dimaksud merupakan kumpulan tanda atau simbol yang bertujuan untuk dipercaya dan dipatuhi (S.R. Rusdiarti, 2003: 33).

Posisi masyarakat yang berada pada pengetahuan yang lemah tentang hal-hal yang mereka hadapi baik menyangkut dengan yang berkaitan dengan agama maupun sosial-politik membuat mereka menggantungkan diri pada teungku dayah baik untuk menjalankan praktik keagamaan maupun memutuskan tindakan politik. Begitu pula, dalam hal yang menyangkut dengan aspirasi-aspirasi mereka, teungku dayah diharapkan dapat memperjuangkannya dan bersikap kritis terhadap pelbagai hal yang menyebabkan kepentingan mereka terganggu atau terancam.

Dalam keadaan seperti itu teungku dayah sebagai elite agama dan sosial didalam masyarakat selain menjadi sandaran rujukan tindakan juga melalui keagensiannya (keaktorannya) diharapkan menjadi penghubung (bridge/mediating dialectical) kepentingan-kepentingan masyarakat dengan negara (struktur). Dengan demikian, keberadaan teungku dayah sebagai agen sangat penting dan menentukan. Praktik tindakan agen (aktor/pelaku) ini menurut Giddens saling terkait dengan struktur. Hubungan keduanya (agen dan struktur) bersifat dualitas tidak dualisme (MarkHaugaard, 1997: 99).

Karena agen dan struktur saling terkait, maka pola hubungan kekuasaan antara keduanya sangat menentukan keberadaan praktik tindakan-tindakan agensi yang dilakukan oleh agen. Apalagi agen yang berasal dari elite agama seperti teungku dayah di Aceh yang kewibawaannya sangat tergan- tung pada kemampuannya menjalankan tindakan praktik agensinya. Sebab masyarakat menilai tindakan agensi teungku dayah sebagai manifestasi dari memperjuangkan kepentingan-kepentingan mereka baik dalam ranah agama maupun politik. Maka analisis sosial yang dilakukan haruslah menemukan pengetahuan bersama (mutual knowledge) dari suatu kesadaran praktis yang menjadi dasar dari praktik sosial itu (Antony Giddens, 1984: 337).

Pengetahuan bersama bukan merupakan rangkaian hal yang dapat dikoreksi melainkan merepresentasi skema interpretatif yang digunakan oleh sosiolog dan aktor awam untuk memahami aktivitas sosial yaitu untuk menghasilkan karakterisasi "yang dapat dikenali" mengenai aktivitas itu. Dengan demikian keterlibatan dalam kehidupan komunitas yang diamati merupakan satu-satunya alat bagi pengamat untuk mampu menghasilkan suatu pemahaman bagaimana mereka berpartisipasi dalam suatu rangkaian praktik sosial tertentu. Hal ini penting sebab menurut Giddens (1976)"Understanding is provided by the reasons or accounts social actors give for their actions. The latter is also associated with the meaning of an event or activity in a particular social context, either that given by social actors or the meaning that researchers derived from social actors' account. Explanations are produced by researchers who looks at a phenomenon from the "outside", while understanding is based on an "inside" view in which researchers grasp the subjective counsciousness, the interpretations, of social actors involved in the conduct".

Karena itu, untuk dapat memberikan penjelasan dari gejala "luar" dan memahami dari "dalam" gejala yang diteliti itu sendiri sebagaimana dikatakan Giddens di atas maka studi ini menggunakan metode etnografi dalam pengumpulan datanya. Namun perlu ditegaskan bahwa studi ini bukanlah sebuah kajian etnografis murni yang berusaha melakukan deskripsi ilmiah sosial tentang manusia dan landasan budayanya secara menyeluruh (holistik-integratif) sebagaimana yang dilakukan oleh para antropolog (Arthur J. Vidich, 1994: 25). Tetapi 
studi ini hanya berusaha untuk menelusuri dan menemukan pengetahuan bersama masyarakat (mutual knowledge) terhadap formalisasi syari'at Islam di Aceh dan bagaimana dampak dominasi negara terhadap keaktoran sosial-politik elite agama Islam tradisional di sana.

Sejalan dengan tujuan tersebut, maka data dikumpulkan melalui kerja observasi partisipan dan wawancara mendalam (indepth interview). Kedua metode ini (observasi partisipan dan wawancara mendalam) dipilih didasarkan pada prinsip sebagaimana disebutkan oleh Atkinson (2001) bahwa kita tidak dapat meneliti realitas sosial tanpa menjadi bagian dari realitas itu sendiri. Selain melalui kedua cara itu, teknik pengumpulan data juga dilakukan melalui studi dokumentasi. Data-data yang diperoleh melalui observasi partisipan dan wawancara mendalam merupakan data primer sementara data yang diperoleh melalui dokumendokumen baik berupa buku, catatan harian, surat keputusan dan dokumen lainnya yang relevan dengan tema studi ini merupakan data sekunder².

Upaya penafsiran terhadap data yang diperoleh baik melalui observasi, wawancara mendalam (indepth interview) dan dokumen dianalisis melalui beberapa tahapan. Pertama tahap reduksi data yang bertujuan melakukan penyeleksian, pemilahan, penajaman, pengorganisasian data ke dalam pola tertentu, kategori tertentu dan tema tertentu. Kedua, tahap display data yang dimaksudkan untuk menyajikan data dalam bentuk sketsa, sinopsis, matrik yang sangat diperlukan untuk memudahkan upaya pemaparan dan penegasan kesimpulan dalam upaya verifikasi data sebagai tahap ketiga.

Proses analisis data tersebut tidaklah dipahami sekali jadi dalam bentuk linier,

2 Primary data are generated by a researcher who is responsible for the design of the study. This is "new" data, used to answer spesific research questions. Secondary data is raw data that have already been collected by someone else, either for some general information purpose, such as a government cencus or other official statistics, or for aspecific research project. Lihat, Norman Blaikie, Designing Social Research, (Cambridge: Polity Press, 2000), hlm 183-184 akan tetapi proses itu mengikuti siklus yang bersifat interaktif dan bolak balik yang sudah dilakukan sejak saat pengumpulan data. Dalam penguraian materi penulisan hasil penelitian ini, dilakukan secara kombinatif antara pengungkapan data dan informasi lalu dianalisis dan diinterpretasikan dengan terlebih dahulu dilakukan sejumlah argumentasi atau penafsiran lalu ditunjukkan data empirisnya.

\section{HISTORISITAS POLITIK FORMAL- ISASI SYARI'AT ISLAM DI ACEH}

Adalah Presiden B.J. Habibie yang pertama kali menggagas perlunya kebijakan politik pusat untuk melegalisasi penerapan syari'at Islam di Aceh. Gagasan itu terekplisitasi pascatumbangnya Orde Baru. Boleh jadi sebagai ideolog ICMI (Ikatan Cendekiawan Muslim Indonesia) pikiran legalisasi syari'at Islam terhadap Aceh sudah ada dibenak Habibie namun kekuasaan dominatif presiden Soeharto membuat ide tersebut diendapkan. Baru tatkala Orde Baru tumbang momentum itu muncul. Legalisasi penerapan syari'at Islam di Aceh pascaOrde Baru terlegitimasi melalui Undang-Undang Republik Indonesia No. 44/1999 tentang Penyelenggaraan Keistimewaan Provinsi Daerah Istimewa Aceh. Disusul kemudian dengan Undang-Undang No. 18/2001 Tentang Otonomi Khusus, sekaligus merubah Provinsi Daerah Istimewa Aceh menjadi Provinsi Nanggroe Aceh Darussalam. Kekuatan legalitas syari'at Islam semakin kokoh keberadaannya tatkala konflik RI-GAM berakhir melalui MOU Helsinki 15 Agustus 2005. Butir-butir perdamaian yang dicetuskan dalam MOU Helsinki itu memberi wewenang yang lebih besar dan tegas terhadap Aceh dalam mengatur rumah tangganya termasuk pelaksanaan syari'at Islam. Lalu secara konstitusional pengukuhan dari MOU Helsinki itu dikukuhkan dalam Undang-Undang No. 11/2006 Tentang Pemerintahan Aceh (Dinas Syari'at Islam Provinsi Nanggroe Aceh Darussalam, 2006).

Namun penerapan syari'at Islam di Aceh bukanlah sesuatu yang lahir secara alamiah, melainkan satu kado politik untuk mengakhiri perang antara pemerintah 
Indonesia dengan Gerakan Aceh Merdeka (GAM). Kenyataannya, konflik panjang dan menyejarah yang dimulai sejak 1976 ini mengalami peningkatan pesat pascaOrde Baru baik secara kualitas maupun kuantitasnya. Perkembangan GAM yang semakin enerjik, sistematis dan mendapatkan dukungan massa yang sangat besar pascapencabutan DOM (Daerah Operasi Militer) 1998 bahkan telah berhasil menempatkan GAM sebagai quasi negara (Ali. et.al, 2008: 179).

Realitas tersebut dapat diamati dalam tiga hal paling pokok, yaitu; diberlakukannya sistem pajak nanggroe (pajak negara), kekuatan militer dan ekspansi kontrol politik atas wilayah. Secara teoritis politik, kontrol terhadap ketiga bidang tersebut merupakan persyaratan minimal bagi kelahiran sebuah negara (Ali. et.al, 2008: 179). Pada mulanya sumber utama pajak GAM ini berasal dari infaq dan shadaqah dari masyarakat. Namun berubah seiring dengan berubahnya ideologi GAM dari ingin membentuk negara Islam menjadi negara sekuler. Sofyan Ibrahim Tiba (seorang juru runding GAM) menegaskan, perjuangan GAM tidak bertujuan mendirikan negara Islam, maka sistem pajaknya tidak lagi atas dasar agama tetapi atas dasar sistem sekuler, yaitu; pajak nanggroe (Nirzalin, 2003: 233).

Sektor lainnya yang menunjukkan mereka telah mencoba mentransformasikan dirinya sebagai sebuah negara adalah melalui kontrol politik dalam kehidupan masyarakat. Di paruh akhir periode 1999 mereka mulai membentuk struktur pemerintahan sipil seperti polisi, hakim, ulama dan kadhi (KUA). Keberadaan kekuasaan GAM juga sangat terasa dalam pemerintahan tingkat desa di mana mereka mampu mendudukkan seseorang menjadi Geuchik (kepala desa) dan mengontrol penuh terhadap kebijakan yang diputuskannya. Karena itu, tidak mengherankan jika di luar kota di Aceh Utara desa-desa sudah dapat dikatakan sebagai desa-desanya GAM³ . PascaOrde Baru, perkembangan militer GAM juga sangat signifikan dengan terbentuknya pasukan "Inong Balee" (pasukan perempu-

3 Wawancara dengan Nasir simpatisan GAM Aceh Utara, 17 Nopember 2008 an). Belakangan pasukan ini disebut juga dengan Asykariah. Sayap militer ini sekaligus menunjukkan bahwa gerakan kemerdekaan Aceh tidak lagi hanya menjadi urusan para lelaki, melainkan telah menjadi urusan semua orang Aceh lintas jenis kelamin dan usia.

Gerakan GAM pascaOrde Baru semakin solid dan massif setelah mereka berhasil pula berkolaborasi dengan para aktivis mahasiswa yang tergabung dalam SIRA (Sentra Informasi Untuk Referendum Aceh). Tekanan yang dilakukan SIRA dibawah label referendum semakin memojokkan pemerintah Indonesia dimata dunia internasional. Keberhasilan sosialisasi referendum terlihat ketika di kemudian hari berduyun-duyun massa dari pelbagai wilayah desa dan kota di Aceh berkumpul di Mesjid Raya Baiturrahman Banda Aceh, menyatakan referendum sebagai satu-satunya koridor penyelesaiaan Aceh.

Referendum dengan tuntutan hanya dua pilihan, yaitu tetap memilih bergabung dengan Indonesia atau berpisah dihadiri tidak kurang dari 500.000 orang. Peristiwa besar yang dilakukan pada Nopember 2000 itu tentu saja menyedot perhatian dunia internasional sebab, kata Martikus: "Press reports talked of how people carried United Nations flags and Banners emblazoned with the word "referendum". (Laporan-laporan Pers melukiskan bagaimana rakyat membawa bendera-bendera Perserikatan BangsaBangsa (PBB) dan panji-panji yang dihiasi kata "Referendum" (Martinkus, dalam Ali, 2008; 195).

Situasi tersebut mendesak pemerintah pusat menemukan solusi cepat sebagai formula meredam pemberontakan di Aceh. Solusi yang ditawarkan tentu saja harus dapat digunakan untuk memperantai dua sasaran, yaitu pertama sasaran internal yang diharapkan dapat menumbuhkan kembali legitimasi NKRI yang sedang krisis di Aceh dan yang kedua eksternal yang berarti dapat dijadikan sebagai "pagar" agar tidak melahirkan dukungan internasional terhadap upaya pemisahan diri dari NKRI yang dilakukan oleh GAM.

Atmosfir politik itulah yang pada ak- 
hirnya mendorong pemerintah Indonesia memilih syari'at Islam sebagai alat politis meredam ekspansi politik GAM. Tentu ini langkah strategis merestorasi krisis negara Indonesia di Aceh. Syariat Islam menyentuh sosio-psikologis orang Aceh sebab mereka adalah penganut Islam fanatik. Hal ini diharapkan dapat mendekatkan kembali hubungan pemerintah Indonesia dengan orang Aceh dan di saat bersamaan diharapkan mengurangi dukungan mereka pada GAM. Sementara bagi dunia internasional terutama Eropa dan Amerika, Islam-phobia masih menjadi realitas yang menghantui.

Kenyataan inilah menurut Haedar (2007), formalisasi syariat Islam di Aceh tidak sepenuhnya murni tumbuh dari gerakan masyarakat tetapi lebih karena akomodasi dan kebijakan politik dalam konteks penyelesaian konflik yang berkepanjangan di wilayah ini sejak era Orde Baru. Legalisasi penerapan syari'at Islam di Aceh sebagai instrumen peredaman konflik bukanlah yang pertama kali karena praktik yang sama pernah dilakukan sebelumnya oleh pemerintah Soekarno pada tahun 1959 yang dimaksudkan sebagai sarana mengatasi pemberontakan DI/TII Aceh yang digerakkan oleh Teungku Muhammad Daud Beureueh (Alyasa' Abu Bakar, 2008: 28). Sebab itu legalisasi syariat Islam jilid II dari pemerintah Indonesia pascaOrde Baru dan konflik ini dapat dimaknai sebagai hasil belajar dari tindakan masa lalu itu.

\section{SYARI'AT ISLAM DAN DOMINASI NEGARA TERHADAP TEUNGKU} DAYAH

Watak politis latar historis legalisasi syariat Islam di Aceh ini ternyata secara kuat mencengkram praktik pelaksanaannya. Pemerintah Aceh sebagai wakil pemerintah pusat mengendalikan dan mengoperasionalisasikan syari'at Islam ini secara politis dan birokratis. Birokratisasi syariat Islam ini dimulai setelah Qanun (Peraturan Daerah) No.33/2001 tentang pembentukan Dinas Syariat Islam Propinsi Nanggroe Aceh Darussalam disahkan pada 2002. Dinas ini bertugas sebagai penanggung jawab perencanaan dan pelaksanaan syari'at Islam di Aceh, terutama dalam kaitannya dengan penyiapan rancangan qanun pengamalan syariat Islam, pembentukan Mahkamah Syari'at di seluruh Aceh, penyiapan tenaga dan sarananya, membantu dan menata penyelenggaraan peribadatan, mengawasi pelaksanaan syari'at Islam serta memberi bimbingan dan penyuluhan tentangnya (Amal dan Panggabean, 2004: 27 dan Abu Bakar, 2005: 2).

Namun, karena bersifat birokratis maka praktik syari'at Islam ini menonjolkan logika positivistik dan mensyaratkan kepemimpinan bersifat legal rasional (Weber, 2009; 238). Kebijakan itu menutup pintu teungku dayah berkiprah dalam struktur formalisasi syari'at Islam. Sebab, teung$k u$ dayah dengan tradisi pendidikan dayah (pesantren tradisional/salafi) yang menekankan pada penguasaan normatifitas teks agama dan kepemimpinan yang menekankan pada kharisma personal dan justifikasi keilahiannya tidak memiliki kemampuan teknis mengurusi birokrasi. Akibatnya, kepemimpinan dalam praktik syari'at Islam pascakonflik tidak berada ditangan teungku dayah sebagai pemimpin Islam masyarakat Aceh tetapi dibawah kendali para sarjana agama Islam khususnya mereka yang berada dijajaran birokrasi pemerintahan.

Keterpinggiran dari struktur ini berimplikasi pula pada terpinggirkannya mereka dalam kewacanaan qanun-qanun syari'at Islam. Sebab pelbagai kebijakan syari'at Islam pada akhirnya diputuskan oleh pemerintah melalui aparatur birokrasinya. Keberadaan teungku dayah yang seolah-olah dilibatkan karena dipublikasikan keberadaaan mereka melalui media massa saat pelbagai qanun tersebut masih berupa rancangan, baik qanun tentang khamar (minuman keras), maisir (judi) dan khalwat (berdua-duan tanpa hubungan pernikahan) yang telah disahkan misalnya lebih bermakna sebagai aktor simbolik daripada aktor yang ikut menentukan.

Pada lain sisi, keberadaan teungku dayah di luar arena atau peripheral zones of the system and discourse dalam konstruksi qanun syari'at Islam ini menjadi persoalan tersendiri pula terhadap citra pengaruh dominan mereka di Aceh. Realitas itu berkai- 
tan dengan eksistensi penguasaan wacana atau pengetahuan yang menjadi salah satu instrumen penting dominannya wibawa yang terakhir di Aceh, seperti yang terhidangkan dalam rentang historis-sosiologis masyarakat Aceh antara 1620-an hingga 1980-an. Pada masa-masa itu, para teungku dayahlah penentu wacana dalam pelbagai kebijakan negara. Hal ini tidak lain karena sebagaimana yang dikatakan oleh Faucault kekuasaan berhubungan erat dengan pengetahuan. Tidak ada pengetahuan tanpa kekuasaan dan sebaliknya tidak ada kekuasaan tanpa pengetahuan. Pengetahuan dan kekuasaan adalah pasangan (Kebung, 2002: 35).

Pada era kerajaan Aceh Darussalam (1513-1942), tampil misalnya Syeikh Hamzah Fansuri, Syeikh Syamsuddin al-Sumaterani, Syeikh Ar-Raniry, Syeikh Abdul Rauf AsSingkili, Teungku Chiek di Tiro, Teungku Chiek Pante Kulu dan Teungku Chiek Kutakarang. Bahkan pada fase ini Aceh mampu menjadi pusat kegiatan intelektual utama di Asia Tenggara dengan teungku dayah sebagai pusatnya. Hal itu terbukti, pada era ini beberapa sarjana dari negara lain datang untuk belajar ke Aceh. Seorang ulama terkenal Syekh Muhammad Yusuf al-Makasari (1626-1699), salah seorang ulama terkenal di zamannya itu misalnya, pernah belajar di Aceh (Bruinessen, 1990:157).

Begitu pula dengan Syeikh Burhanuddin dari Minangkabau yang kemudian menjadi ulama terkenal dan menyebarkan Islam di Ulakan dan mendirikan Surau di Minangkabau merupakan murid kesayangan Syeikh Abdur Rauf al-Singkili (Taufik Abdullah dalam Abdullah \& Siddique. 1988: 986). Syeikh Daud al-Fatani, seorang ulama terkenal Thailand yang berasal dari wilayah muslim Pattani yang sangat produktif dan dihormati karena menjadi seorang guru pula bagi murid-murid muslim Asia Tenggara di Mekkah, pernah pula belajar di Aceh pada tahun 1760-an. Selama di Aceh, yang terakhir belajar pada Syeikh Muhammad Zain al-Faqih Jalal al-Din al-Ashi (Abdullah, 1983: 32). Syeikh Muhammad Zain al-Faqih Jalal al-Din al-Ashi ini adalah seorang pemimpin dayah di Aceh dan penulis dua kitab yang terkenal yaitu Kashf al-Kiraam fi Bayan al-Niyyat $f i$ Takbirat al-Ihram dan Talkhis al-Falah $f \mathrm{Ba}$ yan al-Thalaq wa al-Nikah (Alyasa' Abubakar dan Wamad Abdullah, 1992: 35).

Sejak Syeikh Hamzah Fansuri hingga kedatangan Belanda, ada 13 teungku dayah yang produktif dalam menulis kitab. Kitabkitab mereka yang terkenal bahkan menjadi wacana para intelektual mancanegara mencapai 114 kitab (Alyasa' Abubakar dan Wamad Abdullah, 1992: 35-40). Kitab-kitab yang ditulis tersebut terdiri dari pelbagai macam subjek seperti tasawuf, ilmu kalam (teologi), logika, filsafat,fiqh, hadiths, tafsir, akhlaq, sejarah, tauhid, astronomi, obatobatan, masalah lingkungan dan politik.

Ketika Belanda menyerang Aceh, melalui dominasi kewacanaan pula mereka mampu meng-agensi masyarakat melakukan perlawanan dan mereka sendiri pula yang menjadi panglima perangnya. Pada fase ini mereka menulis kitab-kitab atau hikayat-hikayat yang berisi tentang kewajiban perang sabil (perang jihad fi sabilillah) dan balasan terhadap orang yang gugur di medan perang (perang sabil). Di antara kitab dan hikayat yang ditulis antara lain tulisan Teungku Nyak Ahmad Cot Paleue, Hikayat Prang Sigli tahun 1878 dan Hikayat Nasihat Ureung Muprang tahun 1889. Karya Teungku Chiek Pante Kulu, Hikayat Prang Sabi tanpa tahun, Teungku Chiek di Tiro, Hikayat Nasha'ihu l-Ghazat tanpa tahun, Do Karim, Hikayat Prang Gompeuni tanpa tahun, Hikayat Prang Sabi tanpa tahun, Hikayat Hadzihi Qisah Nafsiyah tanpa tahun dan Hikayat Wasiat Wasiet tanpa tahun. Dan Teungku Kuta Karang menulis kitab, Mau'ithatu-l Ikhwan tahun 1886 dan Tadzkiratur-Rakidin tahun 1889.

Pada masa revolusi dan Orde Lama (1943-1966) tampil Teungku Muhammad Daud Beureueh, Teungku Ahmad Hasballah Inderapuri, Teungku Muhammad Hasan Krueng Kalee, Teungku Abdurrahman Meunasah Meucap, Teungku Abdullah Lam U dan Teungku Syeikh Muhammad Muda Waly al-Khalidy, sebagai pemimpin kewacanaan publik Aceh (Tim Penulis IAIN Ar-Raniry, 2004: 75-193). Kekuatan agensi kewacanaan teungku dayah terhadap ma- 
syarakat dan negara berlanjut dan dominan hingga awal era Orde Baru. Mereka terlibat penuh misalnya dalam perumusan dan implementasi syari'at Islam yang didasari pada Peraturan Daerah (Perda) No. 6/1968, yaitu suatu Perda (saat ini qanun) tentang Ketentuan-Ketentuan Pokok Pelaksanaan Unsur-Unsur Syariat Islam sebagai Pelaksanaan dari status keistimewaan Aceh hasil resolusi konflik dalam perang DI/TII Aceh dengan pemerintah pusat. Pada tahun 1970an para teungku dayah berhasil mendesak pemerintah Aceh menyepakati pelarangan maksiat seperti judi, prostitusi dan minuman beralkohol. Akibatnya, pemerintah pusat tidak berhasil membangun pabrik alkohol di Aceh pada tahun 1984 karena para teungku dayah menentangnya (Amiruddin, 2005: 58-59).

Kekuatan wacana menempatkan teungku dayah menjadi figur kharismatik dan menentukan di Aceh tidak hanya dalam ranah agama tetapi juga dalam aras politik sekaligus. Seruan-seruan politik mereka selalu diikuti oleh masyarakat sebagaimana yang mereka lakukan saat memenangkan partai PPP (Partai Persatuan Pembangunan) dalam Pemilu 1982 dan memenangkan Golkar pada Pemilu 1987 dan 1992. Inilah yang disebut oleh Giddens, penguasaan struktur signifikasi atau wacana pada gilirannya menempatkan seorang aktor (agent) memiliki legitimasi untuk mendominasi pihak lain (Herry Priyono, 2000: 20). Dominasi kewacanaan teungku dayah pada rentang historis Aceh itu menegaskan posisi mereka sebagai penentu "kebenaran" yang dipatuhi.

Realitas lain yang menonjol pada era pascaOrde Baru dan konflik di Aceh adalah semakin intensifnya penetrasi negara terhadap teungku dayah, bahkan dibandingkan dengan Orde Baru sekalipun. Sebab penetrasi kali ini lebih dalam, resmi dan mengikat karena menggunakan agama (syari'at Islam) sebagai instrumennya. Realitas fanatisme keberislaman orang Aceh menuntut legitimasi agama dalam praktik politik pembangunan karena itu hubungan mesra antara pemerintah dengan elite agama menjadi keniscayaan. Kredo ini dianut sebagai mimesis (peniruan) dari praktik sama yang dilakukan oleh negara Orde Baru sebelumnya.

Formalisasi syari'at Islam oleh elite negara yang sedang memerintah justeru dimaknai sebagai momentum, instrumen dan sekaligus justifikasi untuk menjalin hubungan "baik" dengan teungku dayah. Namun, sebenarnya hubungan ini bersifat dominatif dan subordinatif. Upaya menjalin hubungan dengan teungku dayah ini dilakukan melalui pembentukan badan khusus yang bertugas memberdayakan dayah. Lembaga tersebut adalah Badan Pembinaan Pendidikan Dayah (BPPD). Institusi ini kokoh berdiri melalui Qanun No. 5/2007.

Realitasnya, kehadiran lembaga itu melegalkan penetrasi negara terhadap dayah. Padahal pada era-era sebelumnya relatif "bersih" dari intervensi negara semacam itu. Pada era Orde Baru misalnya, sebagai era yang selalu menyandarkan legitimasi kekuasaannya di Aceh pada teungku dayah tidak dibentuk lembaga khusus semacam ini. Operasionalisasi dominasi negara diupayakan hanya melalui keuletan aparatus Golkar yang dipimpin oleh Gubernur Ibrahim Hasan dan pejabat ABRI (Iskandar, 2003: 221-305).

Melalui birokratisasi syariat Islam ini negara memperdalam tancapan dominasinya terhadap teungku dayah di Aceh. Strategi mengalihkan sumberdaya ekonomi dayah dari masyarakat ke negara berhasil membuat teungku dayah terjinakkan dan masuk dalam lingkaran kekuasaan elite negara yang sedang berkuasa. Pada 2008, pemerintah Aceh mengucurkan bantuan untuk dayah sebesar Rp. 164,5 milyar. Dana yang disalurkan kepada 700 lebih dayah itu masing-masing Rp. 102,5 milyar untuk rehab fisik dayah, Rp. 5 milyar untuk pembelian kitab, Rp. 15, 644 milyar untuk pembangunan 172 dayah, Rp. 1,2 miliar untuk 10 Darul Aytam, Rp. 14,5 miliar untuk insentif guru (teungku dayah dan teungku rangkang) dan selebihnya untuk peralatan dayah lainnya (Surat Kabar Harian Aceh, Kamis 14 Agustus 2008: 1)

Besar kecilnya bantuan sangat tergantung pada standar besar kecilnya dayah berdasarkan penilaian BPPD. Oleh BPPD dayah 
dibagi kedalam 4 (empat) tipe yaitu tipe A, B, C dan D. Masing-masing tipe diukur berdasarkan banyaknya jumlah murid dan teungku pengajarnya. Pada 2008, menurut Bustami, Kepala Badan Pembinaan Pendidikan Dayah Aceh, dayah tipe A diberikan bantuan sebesar Rp. 300 juta, tipe B Rp. 250 juta, tipe C Rp. 200 Juta serta tipe D Rp. 150 juta (Harian Serambi Indonesia, 8 Juni 2008: 13).

Namun 2009, bantuan ke dayah mengalami penurunan dari Rp. 164,5 milyar pada 2008 menjadi Rp. 104,7 milyar pada 2009. Penurunan bantuan kepada dayah pada tahun 2009 ini dipengaruhi oleh menurunnya pendapatan Aceh dari sektor migas yang menjadi salah satu sumber utama bantuan dana untuk dayah itu. Konsekuensinya dayah dengan tipe A yang sebelumnya mendapat Rp. 300 juta menjadi Rp. 200 juta, B, dari Rp. 250 juta menjadi Rp. 170 juta, C dari Rp. 200 juta menjadi Rp. 130 juta dan D dari Rp. 150 juta menjadi Rp. 100 juta (Wawancara dengan Jakfar Sulaiman, Staf Pegawai Badan Pembinaan Pendidikan Dayah, 4 Januari 2010).

Derasnya bantuan yang mengalir menyebabkan ketergantungan ekonomi dayah terhadap negara tidak dapat dihindarkan. Apalagi bantuan tersebut tidak hanya berupa bantuan pembangunan fisik tetapi yang sangat penting mencakup pula bantuan insentif (gaji) pada teungku dayah. Sebelumnya, ekonomi dayah bersumber dari produksi ekonomi dayah sendiri seperti pertanian dan perternakan ditambah dengan harta yang dikeluarkan masyarakat berdasarkan perintah dan anjuran agama Islam seperti zakat, infaq, shadaqah, nadzar dan sebagainya (Sufi dkk, 2003: 12).

Kemandirian ekonomi dayah pada negara itu melahirkan hubungan akrab antara teungku dayah dengan masyarakat. Lalu secara psikologis mendorong teungku dayah senantiasa berusaha membela dan memperhatikan masyarakatnya. Melalui keberadaannya yang independen inilah dalam sejarah politik Aceh, teungku dayah mampu menempatkan dirinya sebagai aktor yang selalu mampu bersikap kritis terhadap kebijakan negara yang dinilai melenceng, baik dari kacamata agama maupun kepentingan masyarakat. Namun, realitas ketergantungan ekonomi teungku dayah pada negara telah berhasil merubah posisi hubungan kedekatan teungku dayah dari intim bersama masyarakat menjadi "berselingkuh" dengan elite negara yang sedang memerintah.

Sebab, bantuan-bantuan negara terhadap dayah yang mengalir deras ini bersama dengan mekanisme dan birokrasinya telah menjerat teungku dayah berada dalam sangkar besi kekuasaan negara ${ }^{4}$. Atas nama administrasi, keterbukaan dan transparansi yang dijadikan prinsip utama dan prasyarat dalam penyaluran dana dayah itu sebenarnya mengandung kode pengawasan (surveillance) dan penetrasi tersembunyi negara terhadap teungku dayah. Faucault menyebut kode pengawasan tersembunyi ini sebagai sistem panoptik. Dalam sistem panoptik ini hubungan kekuasaan menjadi total dan tidak bersifat fisik. Sebagai suatu bentuk obsesi rasionalisasi, panoptik berfungsi seperti orthopedi sosial. Ia merupakan sistem tersembunyi sebagai kekuasaan yang berjalan. Suatu fungsi yang dirasakan umum tetapi tidak bisa dikenali (kecuali dari akibatakibatnya). Dari segi politik ia adalah suatu bentuk kontrol yang tidak kelihatan tetapi secara halus memaksa untuk patuh (Kebung, 200: 35). Kontrol dan isolasi ekspresi kritis itu merupakan ongkos dari bantuanbantuan yang mengalir tersebut. Hal ini membenarkan aksioma politik bahwa tidak ada makan siang gratis. Artinya, semua yang diberi harus dibayar melalui tindakan kepatuhan terhadap kekuasaan yang memberi.

\section{DOMINASI NEGARA DAN KRISIS WIBAWA POLITIK TEUNGKU DAYAH}

Dominasi negara dalam formalisasi syari'at Islam di Aceh memberi efek ganda terhadap teungku dayah. Pertama pudarnya peran mereka sebagai aktor civil society dan kedua wibawa politik mereka yang sebelumnya dominan dalam masyarakat Aceh berubah menjadi krisis. Realitas pertama terepsentasikan pada melemahnya kemampuan mereka memediasi aspirasi masyara-

4 Wawancara dengan Hasbi Amiruddin, Guru Besar IAIN Ar-Raniry Banda Aceh, 14 Januari 2010 
kat terhadap pemerintah. Sebagai aktor civil society sejatinya mereka adalah figur yang dituntut mampu menjadi penyambung aspirasi (mediating dialectical) antara masyarakat dan pemerintah (Alexis De Tocqeville, 1956: 109-127). Namun ketergantungan ekonomi yang besar terhadap negara sebagaimana yang diuraikan di atas menyebabkan mereka tidak mampu lagi melakukan hal itu.

Teungku dayah terseret dalam pusaran kekuasaan elite yang sedang pemerintah. Hal ini memaksa mereka bungkam terhadap praktik kekuasaan negara. Meskipun masyarakat membutuhkan intervensi teungku dayah. Pelbagai isu yang seharusnya teungku dayah ikut bersuara misalnya lambatnya kemajuan penerapan syariat Islam, kekerasan Pemilukada (Pemilihan Kepala Daerah), tingginya angka kemiskinan dan massifnya praktik korupsi dalam pengelolaan pemerintahan Aceh pascakonflik nyatanya tidak mendapat reaksi dari mereka.

Kasus menonjol terakhir di mana teungku dayah diharapkan kehadirannya namun ia tetap memilih absen adalah kasus qanun wali nanggroe dan lambang serta bendera Aceh. Pascakonflik, politik lokal Aceh diwarnai oleh sirkulasi elite politik dari elite yang terdidik dengan ideologi NKRI (Negara Kesatuan Republik Indonesia) menjadi elite yang berasal dari mantan kombatan GAM. Setelah damai motivasi para mantan elite pemberontak (GAM) ini mengalami perubahan radikal pula. Jika pada era sebelumnya mereka mengangkat senjata untuk memisahkan diri dari Indonesia maka saat ini ingin mengambil alih semua struktur pemerintahan di Aceh. Keinginan subtansial ini mendorong mereka melakukan gerakangerakan politik strategis.

Selain dilakukan melalui pembentukan struktur partai (Partai Aceh/PA) sampai ketingkat desa (DPG/Dewan Pimpinan Gampoeng) juga melalui penyusupan kepentingan lewat konstitusi (qanun) pemerintah Aceh. Strategi terakhir dijalankan melalui pemanfaatan kekuasaan yang mereka raih baik di legislatif maupun eksekutif. Upaya konstitusionalisasi kepentingan strategis politik mereka ini di antaranya tertuang dalam qanun wali nanggroe dan lambang serta bendera Aceh. Dengan berlindung dibalik MOU Helsinki 2005 point.1.1.5 dan Undang-Undang Pemerintahan Aceh No. 11 tahun 2006 pasal 246 yang menyebutkan bahwa Aceh dapat membentuk lambang dan bendera daerah sendiri yang mencerminkan kekhususan dan keistimewaan Aceh selain dapat pula membentuk kelembagaan adat (Wali Nanggroe) mereka mensahkan qanun (Perda) tentang wali nanggroe dan lambang serta bendera Aceh.

Kedua konstitusi Aceh itu oleh kelompok masyarakat yang kontra disinyalir sebagai konstitusi yang penuh intrik untuk melanggengkan kekuasaan mantan kombatan GAM di Aceh. Sebab dari segi strategi dan taktik yang dijalankan terlihat mencontoh apa yang dilakukan oleh Golkar (Golongan Karya) di masa Orde Baru. Hal ini membenarkan tesis Cakhravorty Spivak, bahwa daerah jajahan cenderung meniru apa yang dilakukan oleh penjajahnya pascajajahan berakhir.

Qanun No. 7 Tahun 2012 tentang wali nanggroe mendapat tantangan keras dari masyarakat Aceh yang berasal dari etnis minoritas non Aceh seperti Gayo, Alas, Aneuk Jame dan sebagainya. Resistensi ditujukan terutama terhadap pasal 69 tentang pejabat wali nanggroe yang persyaratannya mengharuskan putra Aceh asli. Meskipun dalam qanun ini dijelaskan pula bahwa orang Aceh asli adalah semua etnis asli yang ada di Aceh namun kelompok etnis minoritas mencurigai qanun itu adalah topeng etnis mayoritas Aceh untuk mendominasi kekuasaannya di Aceh. Sementara Qanun No. 3 Tahun 2013 tentang Lambang dan Bendera Aceh mendapat tantangan lebih massif dari kelompok masyarakat Aceh. Jika qanun tentang wali nanggroe ditentang oleh kelompok orang Aceh yang beretnis non Aceh yang minoritas maka qanun Lambang dan Bendera Aceh selain mendapat tantangan dari masyarakat beretnis non Aceh juga oleh masyarakat beretnis Aceh sendiri khususnya yang mendiami wilayah pantai barat Aceh.

Dalam qanun terakhir disebutkan bahwa lambang Aceh adalah singa burak 
dan bendera adalah bendera bulan bintang dengan warna dasar merah. Hampir tidak terdapat pro kontra terhadap lambang Aceh terbaru menggantikan lambang panca cita sebelumnya. Namun terhadap bendera pro dan kontra di tengah-tengah masyarakat begitu kuat. Masalahnya bendera yang disahkan dalam qanun Aceh tersebut mirip dengan bendera GAM di masa konflik. Daerah-daerah di kawasan pantai timur menyambut secara antusias bendera ini sebab kedekatan mereka dengan GAM dan bahkan mereka merupakan pendukung utama GAM dimasa konflik. Hadirnya bendera ini dipandang sebagai satu kemenangan politik dengan pemerintah Indonesia 5 .

Sebaliknya, masyarakat di wilayah tengah, barat dan selatan meskipun tidak semua, menolak keras bendera ini. Mereka menganggap bendera tersebut merupakan upaya generalisasi orang Aceh sebagai GAM. Padahal menurut mereka tidak semua orang Aceh adalah GAM. Mereka sendiri adalah orang Aceh tapi mereka bukan GAM. Bendera bulan bintang bukan bendera Aceh sebab tidak ada dalam sejarah Aceh bendera itu digunakan oleh kesultanan Aceh di masa lalu. Bendera itu adalah bendera baru yang dibuat oleh Hasan Tiro untuk kepentingan perang. Menerima bendera itu sama artinya dengan menerima GAM sebagai representasi orang Aceh, kata Teungku Malem ${ }^{6}$.

Resistensi terhadap bendera bulan bintang ini tidak sebatas pada kewacanaan namun aksi penolakan juga dilakukan melalui demonstrasi yang diikuti oleh ribuan massa. Di Aceh Barat pengibaran bendera bulan bintang di pantai timur dan sebagian Aceh Besar dibalas dengan menaikkan bendera merah putih (Harian Serambi Indonesia, 4 April 2013). Di Takengon demonstrasi diikuti dengan penurunan dan pembakaran bendera bulan bintang (Harian Serambi, 28 Juli 2013). Pada gilirannya konflik vertikal yang terjadi dalam dua kasus qanun ini bukan mustahil dapat merambat pada konflik horizontal karena pengerasan pertentangan

5 Wawancara dengan anonim (35 tahun) simpatisan Partai Aceh, warga Aceh Utara 28 Juli 2013

6 Wawancara dengan Teungku Malem (nama samaran) warga Aceh Barat, 25 Juni 2013 yang juga mulai mengarah pada masyarakat akar rumput. Jelas kasus terakhir ini mengancam integrasi sosial masyarakat Aceh. Etno nasionalisme Aceh yang terbentuk sejak ratusan tahun lalu berada diambang kehancuran. Rajutannya mulai terkoyak.

Sayangnya, hiruk pikuk horizon sosial Aceh akibat dari persoalan terakhir inipun tidak terlihat kehadiran teungku dayah memediasi aspirasi masyarakat yang saling bertolak belakang ini. Padahal, memediasi aspirasi masyarakat terhadap elite pemerintahan Aceh adalah sesuatu yang lazim mereka laksanakan pada era-era sebelumnya. Teungku dayah tidak mendesak wacana alternatif terhadap negara dan tidak pula bersikap kritis terhadap pelbagai realitas terakhir. Mereka bungkam dan kehilangan kemampuan menjadi aktor civil society utama di Aceh. Akibatnya, pascakonflik mantan kombatan GAM tampil sebagai aktor tunggal dalam ranah politik Aceh. Realitas ini menyebabkan absennya keseimbangan kekuasaan (check and balance) dalam perpolitikan Aceh.

Sementara krisis wibawa politik teungku dayah terepresentasi pada melemahnya pengaruh agensi politik mereka dalam memenangkan figur-figur tertentu dalam Pemilihan Kepala Daerah (Pemilukada). Begitupula dengan partai politik lokal yang mereka didirikan, PDA (Partai Daulat Aceh) tidak memperoleh sambutan yang berarti dari masyarakat. Partai terakhir tidak berhasil memenangkan suara dipelbagai wilayah Aceh dalam Pemilu Legislatif tahun 2009 kecuali satu kursi di DPRA (Dewan Perwakilan Rakyat Aceh). Pada Pemilukada 2006, figur politik yang didukung oleh teungku dayah untuk jabatan Gubernur adalah pasangan Humam Hamid dan Hasbi Abdullah sementara untuk Bupati salah satunya Tarmizi A. Karim dan Amirullah di Aceh Utara. Hasilnya kandidat yang didukung oleh teungku dayah untuk jabatan Gubernur hanya memperoleh $16,62 \%$ suara kalah dengan pasangan jalur independen Irwandi Yusuf dan Muhammad Nazar yang memperoleh 38,20\% suara. Begitupula dengan kandidat untuk Bupati Aceh Utara hanya berhasil meraih 20,8\% suara dika- 
lahkan oleh pasangan dukungan dari GAM (Gerakan Aceh Merdeka) Ilyas. A. Hamid dan Syarifuddin yang memperoleh $67,4 \%$ suara (Komisi Independen Pemilu Nanggroe Aceh Darussalam, 2006).

Melemahnya wibawa politik teungku dayah ini membuka jalan bagi aktivis GAM menjadi aktor politik utama di Aceh. Hal itu tercermin pada keberhasilan mereka meraih hampir semua jabatan politik di Aceh dalam semua Pemilukada dan Pemilu Legislatif yang di gelar di Aceh sejak 2006 hingga dengan 2012. Bahkan Pemilukada 2012, teungku dayah justeru "tiarap" dalam hingar-bingar pertarungan politik lokal. Sebab, suara politik teungku dayah yang biasanya mengagensi figur-figur tertentu sebagai calon gubernur maupun bertarung sendiri dalam perpolitikan Aceh kini tidak berdaya. Melemahnya pengaruh politik teungku dayah membuat elite politik tidak lagi menjadikan mereka sebagai mesin pendulang suara. Begitu pula kenyataan politik yang menunjukkan masyarakat tidak lagi mengikuti seruan-seruan politik praktis teungku dayah membuat mereka tidak lagi bernafsu ikut dalam pertarungan politik Aceh.

Perubahan sikap masyarakat dalam menilai agensi politik teungku dayah selain pada kualitas personal juga terkait erat dengan perubahan konsepsi mereka terhadap ideologi politik teungku dayah. Agensi politik teungku dayah saat ini dinilai oleh masyarakat tidak lagi dilandasi oleh kepentingan memperjuangkan Islam (ideologis) tetapi hanya memperjuangkan kepentingan politik praktis mereka sendiri ${ }^{7}$. Realitas ini mendorong masyarakat melakukan tafsir ulang terhadap ketakziman (ketundukkan) mereka kepada teungku dayah dalam ranah politik. Hasil tafsir ulang itu sebagaimana yang ditunjukkan oleh hasil Pemilukada di atas, masyarakat menentukan sendiri secara otonom pilihan politiknya.

Akumulasi ketidaksukaan orang Aceh terhadap teungku dayah dalam ranah politik mendorong mereka melakukan penyeberangan politik dari mengikuti ke mana

7 Wawancara dengan Nasrullah, Muzakir, Nurdin dan Badruzzaman, warga Simpang Keuramat Aceh Utara, 20, 21 dan 22 Nopember 2008. arahan atau agensi politik teungku dayah menjadi beralih pada GAM sebagaimana yang direpsentasikan dalam Pemilukada gubernur, bupati dan pemilu legislatif di Aceh. Tindakan peralihan pilihan politik masyarakat dari teungku dayah ke GAM ini merupakan tindakan nyata resistensi dan hukuman dari mereka terhadap yang terakhir karena dinilai tidak lagi dapat dijadikan sebagai referensi politik.

\section{SIMPULAN}

Formalisasi penerapan syariat Islam di Aceh pascaOrde Baru dan konflik merupakan bagian strategi politik pemerintah Indonesia untuk mengatasi krisis legitimasinya di Aceh akibat dari pelbagai ekses tindakan militerismenya dalam konflik panjang dengan GAM (Gerakan Aceh Merdeka). Ternyata watak politis latar belakang penerapannya ini dominan pula mewarnai praktik pelaksanaannya. Realitasnya, elite pemerintahan Aceh sendiri memposisikan syari'at Islam sebagai instrumen strategis untuk melanggengkan kekuasaannya. Tujuan terakhir tercapai apabila teungku dayah sebagai pemimpin Islam di Aceh berhasil dijadikan sebagai aktor simbolik untuk menjustifikasi kekuasaannya. Masalahnya, sebagai pemimpin politik yang berasal dari GAM (Gerakan Aceh Merdeka) satu sisi mereka berkepentingan mematahkan persepsi sebagian publik Aceh yang terlanjur percaya bahwa GAM adalah gerakan perlawanan yang berideologi sekuler (nasionalisme Aceh bukan Islam) dan disisi lain keberadaan teungku dayah dalam jaringan kekuasaannya mendorong dukungan massif terhadap kekuasaannya sebab disadari bahwa orang Aceh adalah pemeluk Islam fanatik. Berangkat dari motif politik tersebut maka syari'at Islam di Aceh dioperasionalisasikan secara birokratis.

Birokratisasi ini menjamin kontrol negara bersifat komprehensif terhadap syariat Islam. Sebab mekanisme birokrasi meniscayakan kepemimpinan strukturalnya berasal dari pegawai negeri sipil yang secara konstitusional merupakan bagian dari pemerintah. Namun di sisi lain pada saat bersamaan meminggirkan elite agama 
Islam tradisional di Aceh yaitu teungku dayah dari arena itu. Sebab praktik syari'at Islam yang birokratis ini menuntut bangunan pengetahuan rasional, kontekstual, efisien dan pragmatis, sementara bangunan pengetahuan teungku dayah bersifat tradisional dan tekstual sehingga antara syari'at Islam dengan teungku dayah terdapat diskrepansi (jarak).

Di ruang yang lain, realitas masyarakat Aceh yang fanatik terhadap Islam sehingga keterikatan mereka dengan teungku dayah sangat kuat membuat rezim pascaOrde Baru di Aceh membutuhkan justifikasi mereka guna melekatkan citra bahwa elite yang sedang memerintah tersebut merupakan elite yang Islami. Lalu hal ini mendorong rezim pascaOrde Baru di Aceh menggunakan syari'at Islam sebagai fasilitas untuk mendominasi kekuasaannya terhadap teungku dayah sehingga mereka dapat digunakan untuk kepentingan simbolik kekuasaannya.

Pada posisi inilah keberadaan syariat Islam di Aceh justru lebih bermakna permainan atau dagangan kekuasaan (komodifikasi) karena digunakan sebagai sumberdaya elite pemerintah untuk mendominasi kekuasaannya terhadap teungku dayah daripada suatu hukum agama yang mentradisi dan mengkultural yang memberi ruang bagi pelbagai komponen sosial untuk berpartisipasi di dalamnya. Operasionalisasi praktik dominasi kekuasaan rezim pascaOrde Baru pada teungku dayah ini pada gilirannya mencerabut independensi dan menjinakkan sikap kritis mereka terhadap negara. Akibatnya, keberadaan teungku dayah sebagai aktor civil society utama di Aceh yang mampu menjadi mediator politik antara kepentingan masyarakat dengan negara pun mengalami kepudaran (melemah).

Hilangnya kemampuan teungku dayah menjadi aktor sosial ini memberi dampak krisis pula kewibawaan politik mereka di Aceh. Sebab kewibawaan politik teungku dayah di Aceh selain dibangun dari justifikasi Islam juga yang sangat penting pada peran-peran keaktoran sosial mereka. Kenyataan ini tereprsentasi pada hilangnya kemampuan mereka memenangkan figur- figur pemimpin politik dalam Pemilukada (Pemilihan Kepala Daerah) Aceh, baik Pemilukada gubernur, walikota/bupati maupun Pemilu legislatif. Begitu pula dengan partai politik yang mereka dirikan yaitu Partai Daulat Aceh (PDA) hanya mampu meraih satu kursi di Dewan Perwailan Rakyat Aceh (DPRA). Sementara di kabupaten/kota gagal total. Realitas ini mengkondisikan mantan kombatan GAM menjadi penguasa tunggal dalam ranah politik Aceh aktual. Akibatnya, cheks and balances kekuasaan politik di Aceh relatif tidak terjadi.

\section{DAFTAR PUSTAKA}

Atkinson, P.(eds). 20o1. Handbook of Ethnography, London: Sage Publication

Alfian. 1975. The Ulama In Achehnese Society : A Preliminary Observation. Bangkok: Friedriech Ebert Stiftung

Abdullah, T.. \& Sharon S.(eds). 1998. Islam and Society in Southeast Asia. Singapore; Institute of South East Asian Studies. .1987. Islam dan Masyarakat, Pantulan Sejarah Indonesia. Jakarta: LP3ES

Abdullah, H.W. Shaghir. 1983. Sheikh Daud bin Abdullah al-Fatani: Ulama dan Pengarang Terulung Asia Tenggara. Kuala Lumpur; Hizbi.

AW. B. 1999. "Senyum Seorang Teungku", Banda Aceh: Jurnal Nanggroe

Ali, F. et.al. 2008. Kalla E Perdamaian Aceh. Jakarta; LSPEU.

Abu Bakar, Alyasa', 2002. Syari'at di Wilayah Syari'at, Pernik-Pernik Islam di Nanggroe Aceh Darussalam, Banda Aceh: Dinas Syariat Islam Provinsi Nanggroe Aceh Darussalam.

. 2005. Bunga Rampai Pelaksanaan Syari'at Islam, Pendukung Qanun Pelaksanaan Syari'at Islam. Banda Aceh: Dinas Syari'at Islam Propinsi Nanggroe Aceh Darussalam. 1992. "Manuskrip Dayah Tanoh Abee Kajian Keislaman di Aceh Pada Masa Kesultanan”, Jurnal Kajian Islam, 2

Amal, T.A dan Samsul Rizal Panggabean. 2004. Politik Syariat Islam Dari Indonesia Hingga Nigeria. Jakarta; Pustaka Alvabet.

Amiruddin, M.H. 2005. The Response ot the Ulama Dayah to the Modernization of Islamic Law in Aceh. Malaysia; UKM.

T.B. Bottomore,T.B. 2006. Elite dan Masyarakat. Jakarta: Akbar Tanjung Institute

Benda. J. H. 1985. Bulan Sabit dan Matahari Terbit, Islam Indonesia Pada Masa Pendudukan Jepang, Jakarta: Pustaka Jaya

Dhofier, Z. 1982. Tradisi Pesantren, Studi Tentang Pandangan Hidup Kyai. Jakarta: LP 3 ES.

Denzin. K.N. \& Yvonna S. Lincoln (eds), 1994. Hanbook of Qualitative Research, London: SAGE 
105 Nirzalin dan Fakhrurrazi, Formalisasi Syariat Islam dan Dominasi Negara terhadap Elite

Publication

Dinas Syari'at Islam Provinsi Nanggroe Aceh Darussalam. 2006. Himpunan Undang-Undang, Keputusan Presiden, Peraturan Daerah/Qanun, Instruksi Gubernur dan Edaran Gubernur Berkaitan dengan Pelaksanaan Syariat Islam. Banda Aceh.

Faucault, M. 2002. Power/Knowledge, Wacana Kuasa/ Pengetahuan. Yogyakarta: Bentang.

Giddens. A. 1984. The Constitution of Society, Outline of The Theory of Structuration. Cambridge UK: Polity Press.

-------. 1976. New Rules of Sociological Method. London: Hutchinson

Iskandar, E.(ed). 2003. Namaku Ibrahim Hasan, Menebah Tantangan Zaman. Jakarta: Yayasan Malem Putra.

Komisi Independen Pemilu. 2006. Nanggroe Aceh Darussalam.

Konrad Kebung. 2002. "Kembalinya Moral Melalui Seks”. Basis. 51(1)

Nirzalin, 2012, Ulama dan Politik di Aceh, Menelaah Hubungan Kekuasaan Teungku Dayah dan Negara. Yogyakarta: Maghza Pustaka

---------, 2003. Pergeseran Legitimasi Kekuasaan Ulama Dalam Masyarakat Aceh. Yogyakarta: Tesis S2 Sosiologi Universitas Gadjah Mada.

----------, 2004. Relasi Kekuasaan Teungku-Murid, Studi di Dayah Tanoh Abeu Kabupaten Aceh Besar. Lhokseumawe: LPPM Universitas Malikussaleh, Penelitian Hibah Propinsi Nanggroe Aceh Darussalam.

Nashier, H. 2006. Gerakan Islam Syari'at, Reproduksi Salafiyah Ideologis di Indonesia. Jakarta: PSAP.

Priyono, H.B. 200o. "Sebuah Terobosan Teoritis". Basis, $49(1)$

Jenkis, R. 2004. Membaca Pikiran Pierre Bourdieu, Yogyakarta: Kreasi Wacana
Siegel, J.T. 2003. The Rope of God. USA: The University of Michigan Press

Syamsuddin, N. 1990. Pemberontakan Kaum Republik, Kasus Darul Islam Aceh. Jakarta: Grafiti.

Sufi, R. dkk, 2003. Peranan Tokoh Ulama Dalam Perjuangan Kemerdekaan 1945-1950 di Aceh. Banda Aceh: Pusat Dokumentasi dan Informasi Aceh.

---------, 2006. Tgk. Hasan Krueng Kalee dan Teuku Nyak Arief, Profil Ulama dan Umara Aceh, Banda Aceh: Badan Perpustakaan Provinsi Nanggroe Aceh Darussalam

Saby, Y. 2000. "A Profile of The Ulama in Achehnese Sociey". Jurnal Al Jami'ah. 38(2)

Tocqville, A. 1956. Democracy in America, New York: Vintage Books

Turmudi, E. 2003. Perselingkuhan Kiai dan Kekuasaan. Yogyakarta: LKiS.

Tim Penulis IAIN Ar-Raniry. 2004. Ensiklopedi Pemikiran Ulama Aceh. Banda Aceh: Ar-Raniry Press.

Weber, M. 1947. The Theory of Social and Economic Organization. New York: Oxford University Press.

--------. 1964. Economy And Society, An Outline of Interpretive Sociology. USA: University of California Free Press

\section{DAFTAR WAWANCARA}

Nasir simpatisan GAM Aceh Utara, 17 Nopember 2008 Hasbi Amiruddin, Guru Besar IAIN Ar-Raniry Banda Aceh, 14 Januari 2010

Anonim (35 tahun) simpatisan Partai Aceh, warga Aceh Utara 28 Juli 2013

Teungku Malem (nama samaran) warga Aceh Barat, 25 Juni 2013

Nasrullah, Muzakir, Nurdin dan Badruzzaman, warga Simpang Keuramat Aceh Utara, 20, 21 dan 22 Nopember 2008. 